\title{
A Decade Trend of Total Factor Productivity of Key State-Owned Forestry Enterprises in China
}

\author{
Hongqiang Yang ${ }^{1,2,3, *}$, Tian Yuan ${ }^{1,3}$, Xiaobiao Zhang ${ }^{1,3}$ and Suyan $\mathrm{Li}^{1}$ \\ 1 College of Economics and Management, Nanjing Forestry University, No. 159, Longpan Road, \\ Nanjing 210037, China; ytnjfu@gmail.com (T.Y.); xiaobiaozhang.njfu@gmail.com (X.Z.); \\ lisuyan1123@163.com (S.L.) \\ 2 Center for the Yangtze River Delta's Socioeconomic Development, Nanjing University, No. 22, \\ Hankou Road, Nanjing 210093, China \\ 3 Research Center for Economics and Trade in Forest Products of the State Forestry Administration, No. 159, \\ Longpan Road, Nanjing 210037, China \\ * Correspondence: yhqnfu@gmail.com; Tel.: +86-25-8542-7378
}

Academic Editors: Thomas J. Straka and Eric J. Jokela

Received: 29 February 2016; Accepted: 26 April 2016; Published: 29 April 2016

\begin{abstract}
State-owned forestry enterprises are important elements of the forestry economy in China. The operational efficiency of such enterprises depends on technological progress and other input factors. Total factor productivity (TFP) is an important means to evaluate the efficiency of technical elements. The growth of production efficiency can be classified into efficiency variation and technical variation. The TFP of 135 key state-owned forestry enterprises in the northeast, southwest, and northwest regions of China in 2001-2011 was measured through Malmquist-data envelopment analysis. The technological progress of the state-owned forestry enterprises positively affected TFP variation, but technical efficiency only slightly increased and scale efficiency even negatively affected TFP variation. The average growth rate of TFP in the northwest region is higher than those in the northeast and southwest regions. The Western Development Program of China increasingly contributes to the economic development of western areas. The increasing investment of the government in science and technology accelerates the development of forestry economy in China.
\end{abstract}

Keywords: key state-owned forestry enterprise; total factor productivity; Malmquist-DEA model; China

\section{Introduction}

Chinese state-owned forestry enterprises are important organizations that integrate economic, ecological, and social functions. In 2011, the output of Chinese fully state-owned forestry enterprises was US $\$ 8.7$ billion, $97 \%$ of which (US $\$ 8.4$ billion) was contributed by 135 key forestry enterprises (wood processing enterprises) [1]. Key state-owned forestry enterprises have become an important part of the Chinese forestry economy. The Natural Forest Protection Project (NFPP) of China has strengthened forest tending and has limited timber harvesting. Thus, the domestic supply of timber raw materials decreased, and the mode of the industrial economic development of key state-owned forestry enterprises needed transformation [2]. Because China has entered into the period of its 12th Five-Year Plan (from 2011 to 2015), the central government needs to gradually shift the aim of the development of the forestry economy from economic benefit to ecological benefit. Thus, key state-owned forestry enterprises have gradually transformed the extensive exploitation of forest resources to eco-effective use, and their industrial development has mainly relied on scientific and technological progress and innovation-driven factors of production. Against this background of the transformation of forestry development, the total factor productivity (TFP) of key state-owned forestry enterprises should be 
examined, and the effect of science and technology elements on forestry economic development should be determined [3].

TFP is regarded as the efficiency of productive factors, including capital, labor, resources, institutional innovations [4]. Decomposed into detailed indicators, such as technical efficiency and scale efficiency [5,6], TFP could be used to evaluate contributors and sustainability of an economy, industry, or enterprise, which is significant to policy-making [7,8]. TFP is an important analysis index in research on industrial production efficiency. The main evaluation involves parametric and non-parametric methods. Parametric methods pre-set an explicit function based on input-output data, but a proper function form is difficult to define. By contrast, non-parametric methods are more practicable and require no function characterization [9]. As a major non-parametric analytical method, data envelopment analysis (DEA) is widely used in forestry economy. Nyrud and Baardsen [10] investigated the production efficiency and productivity growth of Norwegian sawmilling and found that average productivity grew annually and the contribution rate of technological progress increased during the entire survey. However, the overall technical efficiency changed with fluctuation. Tarareh and Saba [11] and Neda and Tarareh [12] measured the TFP of the Canadian wood industry with the Malmquist index. Both studies found that increased productivity significantly benefits from technical change, although the effect of scale efficiency change (SEC) is limited. Chiang [13] proposed time series assessment and used common-weight DEA to estimate the global Malmquist productivity index (MPI) to compare the productivity change of all decision-making units. Results show that the productivity of the forestry industry in most of Taiwan improved.

Liu and Yu [14] evaluated the change trend of technical efficiency, scale efficiency, technological change, and the TFP index of the state-owned forestry industry in northeastern China. Liu and Yu found that the reduction of technical efficiency is the main reason for the reduced TFP of 50 state-owned forestry enterprises in the region. Yang [15] found that the productivity of Chinese national forestry was only slightly high and that regional technical efficiency should be improved. Such factors as scale inefficiency change and low levels of scientific and technological innovation restrict the improvement of technical efficiency. Wang and Han [16] quantitatively estimated and decomposed the efficiency of fund utilization in the Chinese forestry industry on the basis of panel data on 30 Chinese provinces from 1998 to 2010 and of the Malmquist-DEA Index. The rate of contribution of TFP to output indicators, such as the output of the Chinese forestry industry, the average annual wage of on-the-job workers, and afforestation area, is negative, indicating that fund investment in Chinese forestry has not reached the goal of effectively promoting forestry development. Chen et al. [17] measured the TFP of 40 forestry enterprises in Heilongjiang province from 2003 to 2009 and found that although technical efficiency and scale efficiency positively affect TFP change, slow technological progress reduces the TFP index. Because of their different specific objectives and time intervals, these studies on the productivity of Chinese forestry enterprises did not perform inter-regional contrastive analysis. This study used non-parametric methods (such as the Malmquist-DEA model) which based on the input-output data from 2001 to 2011, to estimate the production efficiency and the important influential factors, as well as to evaluate the productivity level and the changing trend of China's state-owned forestry enterprises.

\section{Methodology and Data}

\subsection{Methodology}

Proposed by Farrell [18], DEA is a non-parametric analytical method without a default function. Charnes et al. [19] suggested keeping the input and output of the decision-making unit (DMU) unchanged, which can be projected to the frontier surface by mathematical programming. The relative efficiency of the DMU with multiple input and output factors can be assessed by comparing the degree of deviation from the frontier. Based on the DEA model, several efficiency evaluation indicators, such as the Malmquist index, were defined. 
The Malmquist index was developed by Swedish economist Sten Malmquist [20]. Based on the Malmquist quantity index and the distance function [21], Caves et al. [22] used the Malmquist index to measure TFP change. Färe et al. [23] used the Malmquist index in empirical analysis; this method has been extensively used in academic research. Färe et al. [24] divided the Malmquist index into efficiency change (EC) and technical change (TC). The EC index or catching up to the frontier reflects the efficiency change trend of the DMU during the period $(t, t+1)$. The EC index can further be divided into pure technical efficiency change (PEC) and SEC. The TC index or frontier shift reflects the TC trend at different time points. This evaluation method is important in research on TFP in the financial, agricultural, and other public administration fields.

The Shephard input distance function is defined as

$$
D_{i}^{t}\left(y^{t}, x^{t}\right)=\max \left\{\lambda:\left(x^{t} \mid \lambda\right) \in P^{t}\left(y^{t}\right)\right\}
$$

where $D_{i}^{t}$ is the distance function, $i$ is the distance function based on inputs, and $x^{t}$ and $y^{t}$ are the input and output, respectively, at time point $t$. The reciprocal of the degree of change (increase or decrease) of the proportion of input factors is based on the established production technology and the same level of outputs. $\lambda$ is the increased input as a specific proportion, $P^{t}\left(y^{t}\right)$ is the collection of inputs, and $D_{i}^{t}\left(y^{t}, x^{t}\right)=1$ indicates that the input factor is on the boundary of the isoquant curve.

The Shephard output distance function is defined as

$$
\mathrm{D}_{\mathrm{o}}^{t}\left(x^{t}, y^{t}\right)=\min \left\{\theta:\left(y^{t} \mid \theta\right) \in P^{t}\left(x^{t}\right)\right\}
$$

where $\mathrm{D}_{\mathrm{o}}^{t}$ is the distance function, $o$ is the distance function based on outputs, and $x^{t}$ and $y^{t}$ are the input and output, respectively, at time point $t$ The degree of change of the output is determined by the change of proportion of input factors based on the established production technology and the same level of outputs. $\theta$ is the increased output as a specific proportion, and $P^{t}\left(x^{t}\right)$ is the possibility set of industry production based on the input $x^{t}$ at time point $t$.

The Caves Malmquist productivity index is defined as

$$
\begin{aligned}
\mathrm{M}^{\mathrm{t}} & =\frac{D^{t}\left(x^{t+1}, y^{t+1}\right)}{D^{t}\left(x^{t}, y^{t}\right)} \\
M^{t+1} & =\frac{D^{t+1}\left(x^{t+1}, y^{t+1}\right)}{D^{t+1}\left(x^{t}, y^{t}\right)}
\end{aligned}
$$

Under the assumption of constant returns to scale, the Färe Malmquist index is defined as

$$
\mathrm{M}\left(x^{t+1}, y^{t+1}, x^{t}, y^{t}\right)=\left[\frac{D^{t}\left(x^{t+1}, y^{t+1}\right)}{D^{t}\left(x^{t}, y^{t}\right)} \times \frac{D^{t+1}\left(x^{t+1}, y^{t+1}\right)}{D^{t+1}\left(x^{t}, y^{t}\right)}\right]^{1 / 2}
$$

If $M\left(x^{t+1}, y^{t+1}, x^{t}, y^{t}\right)>1$, comprehensive productivity increases; if $M\left(x^{t+1}, y^{t+1}, x^{t}, y^{t}\right)=1$, comprehensive productivity remains constant; if $M\left(x^{t+1}, y^{t+1}, x^{t}, y^{t}\right)<1$, comprehensive productivity decreases.

When $M\left(x^{t+1}, y^{t+1}, x^{t}, y^{t}\right)=1$ further decomposition occurs:

$$
\mathrm{M}\left(\mathrm{x}^{\mathrm{t}+1}, y^{t+1}, x^{t}, y^{t}\right)=\frac{D^{t}\left(x^{t+1}, y^{t+1}\right)}{D^{t}\left(x^{t}, y^{t}\right)} \times\left[\frac{D^{t}\left(x^{t+1}, y^{t+1}\right)}{D^{t+1}\left(x^{t+1}, y^{t+1}\right)} \times \frac{D^{t}\left(x^{t}, y^{t}\right)}{D^{t+1}\left(x^{t}, y^{t}\right)}\right]^{1 / 2}=E C \times T C
$$

where $\frac{\mathrm{D}^{t}\left(x^{t+1}, y^{t+1}\right)}{D^{t}\left(x^{t}, y^{t}\right)}$ equals $E C$ and is the change of the relative technical efficiency from time point $t$ to $t+1$. This variable describes whether the production unit is close to the production frontier and can be called catching up to the frontier. If $E C>1$, technical efficiency increases; if $E C<1$, technical 
efficiency decreases. $\left[\frac{D^{t}\left(x^{t+1}, y^{t+1}\right)}{D^{t+1}\left(x^{t+1}, y^{t+1}\right)} \times \frac{D^{t}\left(x^{t}, y^{t}\right)}{D^{t+1}\left(x^{t}, y^{t}\right)}\right]^{1 / 2}$ is the frontier shift from time point $t$ to $t+1$. If $T C>1$, technical progress occurs; if $E C>1$, technical retrogress occurs.

If constraint conditions to the distance function increase, the Malmquist index can be measured under the assumption of variable returns to scale (Fare 1994). The EC index can further be divided into $P E C$ and $S E C$ :

$$
M\left(x^{t+1}, y^{t+1}, x^{t}, y^{t}\right)=T C \times P E C \times S E C
$$

where $P E C$ is the TC based on variable returns and $S E C$ is the change of technical deviation between constant returns and variable returns. $\mathrm{SEC}=\mathrm{EC} / P E C$. If $S E C>1$, the industry is close to the long-term optimal scale. Thus, a Malmquist index greater than 1 indicates a positive effect on productivity improvement. By contrast, a Malmquist index less than 1 indicates a negative effect on productivity improvement.

\subsection{Data Acquisition and Index Selection}

All data on the forestry industry from 2001 to 2011 were acquired from the Chinese Forestry Statistical Yearbook. The statistics included data on state-owned forestry enterprises in eight major provinces or regional groups. Based on a different level of regional economic development, the eight regions can be divided into northeast, northwest, and southwest state-owned forest regions. The northeast region includes state-owned forestry enterprises in Inner Mongolia, Jilin, the Great Khingan, and the Longjiang Group; the northwest region includes enterprises in Shaanxi and Gansu; the southwest region includes enterprises in Yunnan and Sichuan. The gross domestic product (GDP) of the forestry enterprises in the eight regions accounts for $94.2 \%$ of the total GDP of Chinese national key state-owned forestry enterprises (Figure 1). Therefore, the key state-owned forestry enterprises in the three major areas reflect the overall TFP of Chinese state-owned forestry enterprises and are thus appropriate research objects.

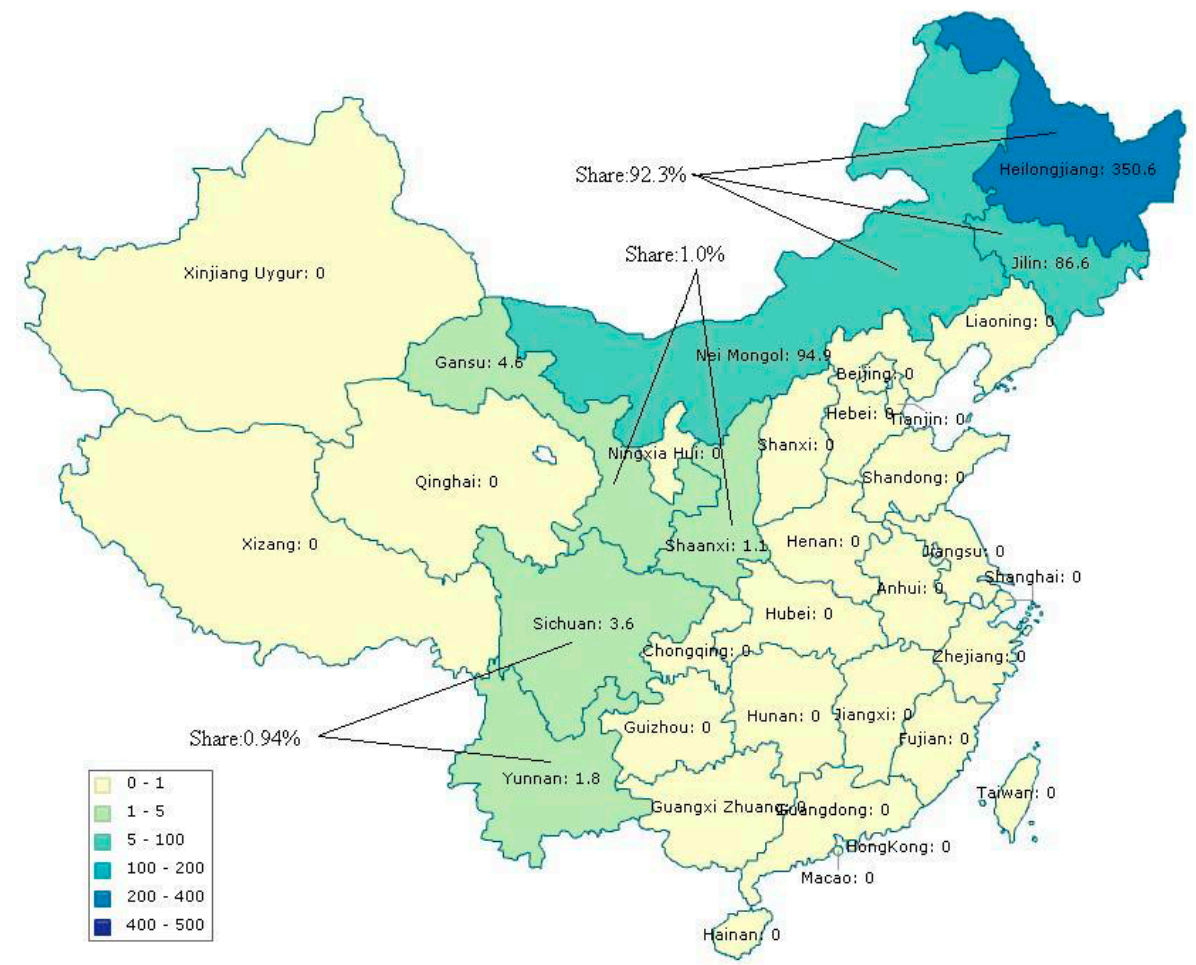

Figure 1. Proportions of gross domestic product (GDP) of key state-owned forestry enterprises in three major regions. 
The choice of input and output variables is the key to adopting the Malmquist-DEA model. Three basic principles of choice are considered. First, the indicator should meet evaluation requirements and objectively reflect the production efficiency of the evaluation object. Second, linear influence between internal input and output indicators should be avoided. Finally, the availability of indicators should be considered. How to choose input and output variables is the main problem in the evaluation of the productivity of state-owned forestry enterprises. In this study, input variables are defined as fixed investment funds, the number of on-the-job workers, and total costs. Given that the contribution of capital to economic growth is difficult to directly measure, the fixed investment fund was used as a proxy for the ability of state-owned forestry enterprises to produce and construct extensions. Considering the availability of data, the sales and total output of the enterprise were used as the output indicators (Table 1).

Table 1. Malmquist data envelopment analysis (DEA)-based system of evaluation indices of production efficiency.

\begin{tabular}{|c|c|c|}
\hline Item & Indicators & Definition \\
\hline \multirow{3}{*}{ Input } & Fixed investment fund & $\begin{array}{l}\text { Investment used for basic construction and } \\
\text { upgrading (Investment in machinery and } \\
\text { equipment positively affects economic and } \\
\text { productivity growth.) }\end{array}$ \\
\hline & $\begin{array}{l}\text { Number of on-the-job } \\
\text { workers }\end{array}$ & $\begin{array}{l}\text { The number of the on-the-job workers is an } \\
\text { important indicator of the proportion of logging } \\
\text { enterprises in state-owned forest regions to the } \\
\text { national economy. }\end{array}$ \\
\hline & Total costs & $\begin{array}{l}\text { Indispensable direct costs of production and sales } \\
\text { of products and services of the state-owned } \\
\text { forestry enterprise }\end{array}$ \\
\hline \multirow[t]{2}{*}{ Output } & Sales & $\begin{array}{l}\text { Total sales revenue of main product of the } \\
\text { state-owned forestry enterprise in a given period. } \\
\text { This revenue reflects the operation and } \\
\text { management status of the enterprise. }\end{array}$ \\
\hline & Total output & $\begin{array}{l}\text { The total output of the state-owned forestry } \\
\text { enterprise in a given period is an important } \\
\text { indicator of economic output. }\end{array}$ \\
\hline
\end{tabular}

Note: these indicators are the production indices of the state-owned forestry enterprises in the Chinese Forestry Statistical Yearbook.

The price index of investment in fixed assets and the production price index of the wood processing industry were used to compare the input indicators, with 2000 as the base year. The ex-factory price index of forest industrial products was used to compare the output indicators.

\section{Results Comparison Based on Malmquist-DEA Model}

\subsection{Analysis of TFP Change from Time Dimension}

Table 2 shows the results of the estimation of the EC, TC, PEC, SEC, and TFP change (TFPC) of Chinese key state-owned forestry enterprises from 2001 to 2011. 
Table 2. Total factor productivity (TFP) variation of Chinese key state-owned forestry enterprises with time.

\begin{tabular}{cccccc}
\hline Period & $\begin{array}{c}\text { Efficiency } \\
\text { Change (EC) }\end{array}$ & $\begin{array}{c}\text { Technical } \\
\text { Change (TC) }\end{array}$ & $\begin{array}{c}\text { Pure Technical Efficiency } \\
\text { Change (PEC) }\end{array}$ & $\begin{array}{c}\text { Scale Efficiency } \\
\text { Change (SEC) }\end{array}$ & $\begin{array}{c}\text { Total Factor Productivity } \\
\text { Change (TFPC) }\end{array}$ \\
\hline $2001-2002$ & 0.858 & 1.172 & 1.046 & 0.820 & 1.006 \\
$2002-2003$ & 1.315 & 2.196 & 1.010 & 0.302 & 2.887 \\
$2003-2004$ & 0.890 & 1.074 & 0.903 & 0.991 & 0.956 \\
$2004-2005$ & 1.096 & 1.124 & 1.106 & 1.005 & 1.232 \\
$2005-2006$ & 0.983 & 1.173 & 0.978 & 1.105 & 1.153 \\
$2006-2007$ & 1.136 & 0.927 & 1.028 & 1.006 & 1.053 \\
$2007-2008$ & 1.018 & 1.043 & 1.013 & 0.953 & 1.062 \\
$2008-2009$ & 0.864 & 1.284 & 0.907 & 1.001 & 1.109 \\
$2009-2010$ & 1.030 & 1.152 & 1.029 & 0.906 & 1.186 \\
$2010-2011$ & 0.886 & 1.184 & 0.978 & 1.001 & 1.049 \\
Average & 0.999 & 1.199 & 0.998 & 1.198 \\
\hline
\end{tabular}

The overall technical improvement rate increased by $19.9 \%$ and thus increased the TFP of state-owned forestry enterprises by $19.8 \%$ from 2001 to 2011 . This result indicates the significant positive effect of the technical improvement rate on TFP. The annual TFP change showed a rising trend during all the periods except from 2003 to 2004. During the periods 2002-2003, 2007-2008, and 2009-2010, increased EC and TC significantly improved TFP. From 2001 to 2002, technical improvement and PEC positively affected the rise of TFP, whereas EC and SEC negatively affected it. Thus, TFP only slightly increased during the period 2001-2002. Technical progress, efficiency, and PEC increased from 2004 to 2005, and TC and SEC increased from 2005 to 2006. In both years, technical advancement was the largest contributing factor to the rise of TFP. During the period 2006-2007, efficiency, pure efficiency, and scale efficiency increased. EC had the greatest positive effect on TFP increase. During the periods 2008-2009 and 2010-2011, only technical progress positively affected the rise of TFP; all other EC indices had a slight negative effect. From 2003 to 2004, TFP declined primarily because efficiency, pure efficiency, and scale efficiency decreased. Technical advancement positively affected TFP change, but this effect was insufficient to offset the negative change because of the strict management of natural forests by the State Forestry Administration [25].

The TFP growth rate can further be divided and analyzed according to the evaluation results in Table 2. National macroeconomic policies and forestry institutional changes may have influenced TFP changes from 2001 to 2011. The average TC rate from 2001 to 2011 was 1.199, indicating that the technology of state-owned forestry enterprises improved. To survive and gain competitive advantage under the forestry economic system, enterprises continuously increase their technical inputs and enhance their technical innovation. Technology improved during all periods except during 2006-2007. Although technical advancement positively affected TFP change in 2004, the market demand, which is usually confined to information asymmetry, consumer preferences, national policies, the gross domestic product (GDP) and so on, cannot be expanded in a very short run, and the poor external economic environment directly reduces economic efficiency [26-30]. Thus, technical progress is insufficient to cover other negative changes. The introduction of technologies to the enterprise involves an assessment of costs and benefits. Decision-making risk decreases the willingness of enterprises to adopt new technology, and limited research budgets and talent scarcity increase the burden of enterprises.

The average annual EC rate from 2001 to 2011 was 0.999 (Table 2), indicating that the technical efficiency of state-owned enterprises did not improve. Thus, enterprises lagged behind the frontier of high and new technology given the technological conditions. The technological innovation of enterprises was insufficient. Low-technology enterprises had difficulty adapting to the operations of the market system.

In conclusion, the TFP growth of state-owned forestry enterprises coincides with the classical theory of economic growth. Technical progress significantly influences economic growth. 


\subsection{Analysis of TFP Change from Spatial Dimension}

Table 3 shows the results of the estimation of the EC, TC, PEC, SEC, and TFP change (TFPC) of key state-owned forestry enterprises on the basis of the spatial dimension.

Table 3. TFP variation of key state-owned forestry enterprises with space.

\begin{tabular}{|c|c|c|c|c|c|c|}
\hline & Region & $\begin{array}{c}\text { Efficiency } \\
\text { Change (EC) }\end{array}$ & $\begin{array}{c}\text { Technical } \\
\text { Change (TC) }\end{array}$ & $\begin{array}{l}\text { Pure Technical } \\
\text { Efficiency } \\
\text { Change (PEC) }\end{array}$ & $\begin{array}{c}\text { Scale Efficiency } \\
\text { Change (SEC) }\end{array}$ & $\begin{array}{c}\text { Total Factor } \\
\text { Productivity } \\
\text { Change (TFPC) }\end{array}$ \\
\hline & China & 0.990 & 1.118 & 1.000 & 0.990 & 1.107 \\
\hline \multirow{4}{*}{ Northeast } & Inner Mongolia & 0.920 & 1.108 & 0.927 & 0.992 & 1.019 \\
\hline & Jilin & 1.000 & 1.129 & 1.000 & 1.000 & 1.129 \\
\hline & $\begin{array}{l}\text { Longjiang } \\
\text { Group }\end{array}$ & 1.000 & 1.118 & 1.000 & 1.000 & 1.118 \\
\hline & Great Khingan & 0.990 & 1.110 & 0.993 & 0.996 & 1.099 \\
\hline \multirow{2}{*}{ Southwest } & Sichuan & 1.102 & 1.403 & 1.066 & 1.034 & 1.547 \\
\hline & Yunnan & 0.929 & 1.214 & 1.000 & 0.929 & 1.128 \\
\hline \multirow{2}{*}{ Northwest } & Shaanxi & 1.031 & 1.178 & 1.000 & 1.031 & 1.215 \\
\hline & Gansu & 1.039 & 1.474 & 1.000 & 1.039 & 1.531 \\
\hline
\end{tabular}

Note: calculated based on data from the Chinese Forestry Statistics Yearbook.

The evaluation results in Table 3 show that the production efficiency of the state-owned forestry enterprises improved and thus significantly affected the development of forestry. From 2001 to 2011, the TFP of forestry enterprises in each region increased, particularly that in Sichuan Province (54.7\%). Technical progress has driven the entire production frontier outward and has thus become a determinant of TFP growth. Positive TC indicates that labour-intensive enterprises undergoing restructuring can adapt to the external environment and enhance development at the cost of large inputs.

From 2001 to 2011, the rate of the average SEC of state-owned forestry enterprises was 1.001. The evaluation result indicates that the overall scale efficiency slightly increased. Scale efficiency decreased in Inner Mongolia and the Great Khingan, remained unchanged in Jilin Province and the Longjiang Group, and increased in other regions. The near constant SEC may result from extensive operation strategy [31], which leads to significant expansion in the scale but disproportionate growth in profits and costs as well as fixed assets and revenues [32]. Thus, how to optimize the production scale of state-owned forestry enterprises still requires further study.

The average TFP of the state-owned enterprises in the three regions increased from 2001 to 2011. (Table 4). The TFP in the northwest area had the most significant increase, followed by that in the southwest and northeast. A certain degree of correlation was found between the efficiency of input utilization of the state-owned forestry enterprises and the level of regional economic development. In 2000, the Chinese government implemented China's Western Development Program (CWDP) to encourage the development of the central and western provinces mainly to support ecological construction, environmental protection, and the construction of key projects, such as infrastructure. The central and western provinces include 12 main provinces and regions: Chongqing, Sichuan, Guizhou, Yunnan, Guangxi, Shaanxi, Gansu, Qinghai, Ningxia, Tibet, Xinjiang, and Inner Mongolia. The government has increased its investment in the western region annually. The proportion of financial investment in the western region increased significantly [33]. The CWDP is implemented through physical capital investment, especially infrastructure investment, to achieve economic growth in the western region [34]. Growing capital investment facilitates regional economic development and promotes regional TFP. 
Table 4. TFP of state-owned enterprises in three regions from 2001 to 2011.

\begin{tabular}{|c|c|c|c|c|c|c|c|c|c|c|c|c|c|c|c|}
\hline \multirow[t]{2}{*}{ Period } & \multicolumn{3}{|c|}{ Efficiency Change (EC) } & \multicolumn{3}{|c|}{ Technical Change (TC) } & \multicolumn{3}{|c|}{$\begin{array}{l}\text { Pure Technical Efficiency } \\
\text { Change (PEC) }\end{array}$} & \multicolumn{3}{|c|}{ Scale Efficiency Change (SEC) } & \multicolumn{3}{|c|}{$\begin{array}{l}\text { Total Factor Productivity } \\
\text { Change (TFPC) }\end{array}$} \\
\hline & North-east & South-west & North-west & North-east & South-west & North-west & North-east & South-west & North-west & North-east & South-west & North-west & North-east & South-west & North-west \\
\hline 2001-2002 & 1.000 & 0.823 & 0.710 & 0.727 & 1.262 & 1.320 & 1.000 & 1.000 & 1.000 & 1.000 & 0.823 & 0.710 & 0.727 & 1.038 & 0.936 \\
\hline $2002-2003$ & 1.000 & 0.622 & 1.588 & 3.363 & 4.460 & 5.838 & 1.000 & 1.000 & 1.000 & 1.000 & 0.622 & 1.588 & 3.363 & 2.773 & 9.273 \\
\hline 2003-2004 & 1.000 & 0.927 & 1.000 & 1.031 & 0.890 & 1.009 & 1.000 & 0.783 & 1.000 & 1.000 & 1.183 & 1.000 & 1.031 & 0.825 & 1.009 \\
\hline 2004-2005 & 1.000 & 1.828 & 1.000 & 1.471 & 0.774 & 0.647 & 1.000 & 1.170 & 1.000 & 1.000 & 1.562 & 1.000 & 1.471 & 1.414 & 0.647 \\
\hline 2005-2006 & 1.000 & 1.202 & 1.000 & 1.031 & 0.859 & 0.779 & 1.000 & 1.091 & 1.000 & 1.000 & 1.101 & 1.000 & 1.031 & 1.033 & 0.779 \\
\hline 2006-2007 & 1.000 & 0.970 & 1.000 & 0.786 & 1.079 & 1.107 & 1.000 & 1.000 & 1.000 & 1.000 & 0.970 & 1.000 & 0.786 & 1.046 & 1.107 \\
\hline 2007-2008 & 1.000 & 0.688 & 1.000 & 0.955 & 1.406 & 1.904 & 1.000 & 1.000 & 1.000 & 1.000 & 0.688 & 1.000 & 0.955 & 0.968 & 1.904 \\
\hline 2008-2009 & 1.000 & 1.389 & 1.000 & 1.122 & 0.955 & 0.913 & 1.000 & 1.000 & 1.000 & 1.000 & 1.389 & 1.000 & 1.122 & 1.326 & 0.913 \\
\hline 2009-2010 & 1.000 & 0.713 & 1.000 & 0.988 & 1.203 & 1.221 & 1.000 & 1.000 & 1.000 & 1.000 & 0.713 & 1.000 & 0.988 & 0.858 & 1.221 \\
\hline 2010-2011 & 1.000 & 0.892 & 1.000 & 0.889 & 1.139 & 1.200 & 1.000 & 1.000 & 1.000 & 1.000 & 0.892 & 1.000 & 0.889 & 1.015 & 1.200 \\
\hline
\end{tabular}

Note: calculated based on data from the Chinese Forestry Statistical Yearbook. 
The pure efficiency of the state-owned enterprises in the three regions remained as 1.0 from 2001 to 2011. The production of all state-owned forestry enterprises in the region did not have a surplus of input factors or efficiency loss. Therefore, the development of the state-owned forestry enterprises mainly depended on technical progress and scale efficiency. The northwest region had the most significant increase in technology change, indicating that the efficiency of the allocation of production resources was higher than in the other two regions. The SEC rate in the northwest area was 1.012, indicating that the northwest region had the most significant rise in scale efficiency. However, the scale efficiency of the other two regions was less than or equal to 1 , suggesting that the state-owned enterprises in the two regions still needed to improve their scale efficiency.

The TFP of the northeast region increased from 2002 to 2006 and from 2008 to 2009. For example, the TFP from 2002 to 2003 increased by $236.3 \%$ because of technical progress. TFP increased mainly because of technological advancement. The EC of resource allocation did not positively affect TFP growth, indicating that the state-owned enterprises in the northeast region should improve their resource allocation efficiency to reduce restrictions on technological development.

The TFP of the southwest area increased during all the periods except 2003-2004, 2007-2008, and 2009-2010.Overall, technological progress and efficiency changes presented opposite dynamics. TFP increase mainly depended on technological improvement. Resource allocation efficiency was further classified into scale efficiency and pure technical efficiency. Resource allocation efficiency changes brought by SEC and TC also presented opposite dynamics. The scale efficiency of the state-owned enterprises in the southwest region had an unstable downward trend. To increase TFP in the market, the enterprises should improve their internal management efficiency and develop their SEC.

The TFP of the northwest area more significantly increased than that of other areas from 2001 to 2011. As in other regions, technological improvement positively affected TFP rise. However, technical efficiency presented an unstable change trend probably because of uneven technical conditions and weak management ability of regional forestry enterprises.

\section{Discussion and Conclusions}

\subsection{Discussion}

The NFPP has protected national forests since 1998, but the reduction of logging timber has hindered the production and operation of forestry enterprises. State-owned forestry enterprises must accelerate the mechanism reform and achieve economic transformation. State-owned forestry enterprises need to increase their technological investment, cultivate technical talent, and establish a system for scientific and technological innovation to promote the upgrading of production equipment and technology. State-owned forestry enterprises must also accelerate the reform of the forestry investment mechanism to perfect the capital utilization mechanism and improve the efficiency of the use of input factors to ultimately stabilize their productivity growth.

This study only used three input factors (fixed investment fund, number of on-the-job workers and total costs) in the model, whereas other uncontrolled factors, such as workforce skills, knowledge and training, were not taken into consideration. The reasons are as follows. Firstly, the input system of DEA model needs quantified data, but factors like skills, knowledge and training are difficult to transform into precise quantified data or the transformation subjects to controversy $[35,36]$. Secondly, it is difficult to cover all the input factors in the Malmquist-DEA model [37]. As a result, this study just chose three representative input factors. Thirdly, these factors are partly included in total costs factor, so that they need not be selected as input factors individually. However, the uncontrolled factors discussed above are important to TFP study, we will try to take them into consideration in following researches. 


\subsection{Conclusions}

This study measured the TFP of state-owned forestry enterprises from 2001 to 2011 through the Malmquist-DEA model. Results show that TFP depends on technological progress and other input factors. Technical progress is the main driver of productivity growth. The TFP of national state-owned forestry enterprises increased from 2001 to 2011. Technical progress positively affected TFP rise. However, EC had a slightly negative effect on TFP because of low pure technical efficiency, a surplus of input factors, or efficiency loss. The TFP of state-owned forestry enterprises in each region increased during the period. The TFP of the northwest area more significantly increased than that of other areas. Since the implementation of CWDP, infrastructure and the investment environment in the west has significantly improved. The proportion of investment in fixed assets to regional GDP became higher than that in the eastern area, and the production efficiency of the forestry enterprises significantly improved. The western region has more space that can be used for economic development [38].

Acknowledgments: This study was supported by the Key Program of the National Social Science Foundation of China (Grant No. 14AJY014), the China Ministry of Education (MOE) Project of Humanities and Social Sciences (Project No. 13YJAZH114), the China Post-doctoral Science Foundation (Grant No. 2012M521058), and the Jiangsu Province Qinglan Project of China (Grant No. 2012JSQLP).

Author Contributions: Hongqiang Yang designed the study and went through all sectional works. Tian Yuan performed the study, analyzed the data and wrote the paper with results checking. Xiaobiao Zhang gave review suggestions for the manuscript on the whole writing process. Suyan Li collected the original data and background materials, analyzed the data, drew the figures and polished the expression. All authors read and approved the final manuscript.

Conflicts of Interest: The authors declare no conflict of interest.

\section{Abbreviations}

The following abbreviations are used in this manuscript:

$\begin{array}{ll}\text { TFP } & \text { Total factor productivity } \\ \text { NFPP } & \text { The Natural Forest Protection Project } \\ \text { DEA } & \text { Data envelopment analysis } \\ \text { SEC } & \text { Scale efficiency change } \\ \text { MPI } & \text { Malmquist productivity index } \\ \text { DMU } & \text { Decision-making unit } \\ \text { EC } & \text { Efficiency change } \\ \text { TC } & \text { Technical change } \\ \text { PEC } & \text { Pure technical efficiency change } \\ \text { GDP } & \text { The gross domestic product } \\ \text { TFPC } & \text { Total factor productivity change } \\ \text { CWDP } & \text { China's Western Development Program }\end{array}$

\section{References}

1. State Forestry Administration. China Forestry Development Report; Chinese Forestry Press: Beijing, China, 2012; pp. 1-6.

2. Yang, H.; Nie, Y.; Ji, C. Study on China's timber resource shortage and import structure: National Forest Protection Program outlook, 1998 to 2008. For. Prod. J. 2010, 60, 408-414. [CrossRef]

3. Wang, C.; Lee, J.; Chang, Y. Measuring productivity in the biotechnology industry using the global Malmquist index. Appl. Econ. Lett. 2012, 19, 807-812. [CrossRef]

4. Hulten, C.R. Total Factor Productivity: A Short Biography; University of Chicago Press: Chicago, IL, USA, 2001; pp. 1-54.

5. Kalirajan, K.P.; Obwona, M.B.; Zhao, S. A decomposition of total factor productivity growth: The case of Chinese agricultural growth before and after reforms. Am. J. Agric. Econ. 1996, 78, 331-338. [CrossRef] 
6. Prescott, E.C. Lawrence R. Klein lecture 1997: Needed: A theory of total factor productivity. Int. Econ. Rev. 1998, 39, 525-551. [CrossRef]

7. Limaei, S.M. Efficiency of Iranian forest industry based on DEA models. J. For. Res. 2013, 24, 759-765. [CrossRef]

8. Zadmirzaei, M.; Limaei, S.; Amirteimoori, A. Efficiency analysis of paper mill using Data Envelopment Analysis models (case study: Mazandaran Wood and Paper Company in Iran). For. Prod. J. 2014, 64, 90-96.

9. Coelli, T.; Rao, D.; O'Donnell, C.; Battese, G. An Introduction to Efficiency and Productivity Analysis, 2nd ed.; Springer Science + Business Media, Inc.: Berlin, Germany, 2005; pp. 25-55.

10. Nyrud, A.; Baardse, S. Production efficiency and productivity growth in Norwegian sawmilling. For. Sci. 2003, 49, 89-97.

11. Tarareh, S.; Saba, V. Malmquist productivity index of the manufacturing sector in Canada from 1994 to 2002, with a focus on the wood manufacturing sector. Scand. J. For. Res. 2006, 21, 424-433.

12. Neda, S.; Tarareh, S. Dynamic efficiency analysis of primary wood producers in British Columbia. Math. Comput. Modell. 2007, 45, 1179-1188.

13. Chinang, K. Malmquist productivity index based on common-weights DEA: The case of Taiwan forests after reorganization. Omega 2010, 38, 484-491.

14. Liu, C.; Yu, F. Efficiency analysis of the Northeast national forest enterprise: DEA approach. Rev. Ind. Econ. 2006, 5, 107-120.

15. Yang, W. Empirical study on TFP of Chinese forestry: DEA approach. J. Beijing For. Univ. 2010, 22, 9-10.

16. Wang, Y.; Han, W. Study on China forest fund utilization efficiency-Based on Dea-Malmquist productivity index. For. Econ. 2012, 8, 95-100.

17. Chen, X.; Gen, Y.; Yu, X. The analysis of the total factor productivity and its influencing factors of forest industry in state-owned region in Heilongjiang province. Probl. For. Econ. 2012, 32, 50-59.

18. Farrell, M. The measurement of productive efficiency. J. R. Stat. Soc. 1957, 120, 253-281. [CrossRef]

19. Charnes, A.; Cooper, W.; Rhodes, E. Measuring the efficiency of decision making units. Eur. J. Oper. Res. 1978, 2, 429-444. [CrossRef]

20. Sten, M. Index numbers and indifference surfaces. Trab. Estad. Investig. Oper. 1953, 4, $209-242$.

21. Shephard, R. Cost and Production Functions; Princeton University Press: New Jersey, NJ, USA, 1953; pp. 1-104.

22. Caves, G.; Christensen, L.; Diewert, W. The economic theory of index numbers and the measurement of input, output, and productivity. Econometrica 1982, 50, 1393-1414. [CrossRef]

23. Fare, R.; Grosskopf, S.; Lindgren, S.; Roos, P. Productivity change in Swedish pharmacies 1980-1989: A non-parametric Malmquist approach. J. Prod. Anal. 1992, 3, 85-101. [CrossRef]

24. Fare, R.; Grosskopf, S.; Norris, M.; Zhang, Z. Productivity growth, technical progress and efficiency change in industrialized countries. Am. Econ. Rev. 1994, 84, 66-83.

25. State Forestry Administration. Advice of State Forestry Administration on the Strict Natural Forest Management. Available online: http://nc.mofcom.gov.cn/news/5402499.html (accessed on 31 March 2016).

26. Wang, L.; Wei, H. Progress of Western China development drive, and evaluation of the results. China World Econ. 2004, 12, 20-33.

27. Liu, S.; Wang, Y.; Hu, A. The effect of Western Development Program and regional economic convergence in China. Econ. Res. J. 2009, 9, 94-105.

28. Wang, X.; Fan, G. Analysis on the regional disparity in China and the influential factors. Econ. Res. J. 2004, 1, 33-44.

29. Lin, Y.; Pan, S. Information asymmetry, adverse selection and economic development. J. World Econ. 2006, 1, 3-12.

30. Huang, W. Information symmetry, market demand and technological innovation of enterprises. Reform Econ. Syst. 2009, 4, 65-69.

31. He, H.; Weng, Q. Ownership, autonomy, incentives and efficiency: Evidence from the forest product processing industry in China. J. For. Econ. 2012, 18, 177-193. [CrossRef]

32. Mather, A.S. Recent Asian forest transitions in relation to forest-transition theory. Int. For. Rev. 2007, 9 , 491-502.

33. Marco, A.; Wander, J. Fashions, habits and changing preferences: Simulation of psychological factors affecting market dynamics. J. Econ. Psychol. 2001, 22, 745-772. 
34. Hang, Q.; Tan, X. Analysis on the influencing factors of farmers' irrigation technology selection. Chin. Rural Econ. 2004, 1, 63-69.

35. Zheng, Y. The measures of total factor productivity and the 'phasic' rules of economic growth-A debate on the way of economic growth in East Asia. Econ. Res. J. 1999, 5, 55-60.

36. Forestry Commission. International Markets in Wood Products. Available online: http://www.forestry. gov.uk/pdf/FCIN060.pdf/\$FILE/FCIN060.pdf (accessed on 31 March 2016).

37. German, C.; Ravikumar, B.; Gustavo, V. Talent, Labor Quality, and Economic Development; Research Division Federal Reserve Bank of Saint Louis: Saint Louis, MO, USA, 2013.

38. Phillip, T. Workforce Skills and Innovation: An Overview of Major Themes in the Literature; OECD Directorate for Science, Technology and Industry, Centre for Educational Research and Innovation: Paris, France, 2011.

(C) 2016 by the authors; licensee MDPI, Basel, Switzerland. This article is an open access article distributed under the terms and conditions of the Creative Commons Attribution (CC-BY) license (http://creativecommons.org/licenses/by/4.0/). 